\title{
Gir sykehussammenslåinger økt effektivitet?
}

En sentral målsetting ved helseforetaksreformen var at den skulle lede til bedret ressursutnyttelse. De statlig eide regionale helseforetakene skulle bidra til en mer effektiv sykehusstruktur og samtidig jevne ut geografiske forskjeller i tilbud og bruk av helsetjenester. Ett av virkemidlene har vært sykehussammenslåinger. Etter reformen er drøyt 50 sykehus blitt til 20 helseforetak. Dels har dette vært administrative endringer med mindre konsekvenser for funksjonsfordeling og innhold, men ofte medfører sykehussammenslåinger reelle strukturelle endringer. I varierende grad har endringene vært initiert og forankret lokalt, ofte har de vært kontroversielle.

Tor Ingebrigtsen og medarbeidere beskriver i dette nummer av Tidsskriftet en sammenslåing av tre sykehus til ett universitetssykehus i Helse Nord (1). De rapporterer om økt aktivitet innen både pasientbehandling og forskning, bedret driftsøkonomi, og små eller ingen endringer for kvalitetsindikatorer og ventetid. Som forfatterne er nøye med å påpeke gir studien ikke grunnlag for å trekke generelle konklusjoner om effekter av sykehussammenslåinger, og de kan heller ikke betraktes som nøytrale observatører. Kontrasten i beskrivelsen fra Helse Nord til den prosessen vi får beskrevet ved Oslo universitetssykehus (2) er imidlertid stor, og utfordrer oss både med tanke på kunnskapsgrunnlaget bak vedtak om sykehussammenslåinger og på hvordan gjennomføringen av disse kan foregå.

Tendensen til at stadig flere sykehus slås sammen er ikke noen særnorsk utvikling, vi ser det samme mønsteret i våre naboland $(3,4)$. Det er imidlertid en generell utfordring at beslutninger om sammenslåing ikke kan støtte seg på dokumentert kunnskap om forholdet mellom størrelse, aktivitetsbredde og (medisinsk og økonomisk) effektivitet. I den grad man kan trekke konklusjoner fra gjennomførte studier, synes de å kunne oppsummeres i fire forhold. For det første finner man ikke noen systematisk bedring i kostnadseffektiviteten etter sykehussammenslåinger (3). For det andre synes utnytting av stordriftsfordeler snarere enn en mer effektiv drift å være hovedforklaringen i de tilfeller hvor man faktisk observerer bedret effektivitet (5). For det tredje kjennetegnes vellykkede sammenslåinger ved at de følges ad av konkrete driftsmessige endringer, og ikke bare er en administrativ endring (6). Endelig synes «ovenfra og ned»endringer å ha begrenset effekt; en vellykket sammenslåing bør også resultere i utviklingen av en felles organisasjonskultur $(4,7)$.

Det kan virke overraskende at man ikke klarer å dokumentere systematiske effekter av sammenslåinger på kostnadseffektivitet. Man ville tro at det er kostnadsbesparende å slå sammen avdelinger/enheter hvor det er ledig kapasitet, eller også å sentralisere en beredskapsfunksjon slik at samme bemanning kan dekke en større befolkningsgruppe. Litteraturen er imidlertid tydelig på at gevinster fra effektivisering ikke kommer av seg selv etter en sammenslåing. For dem som skal utforme politikken blir utfordringen både å vurdere om det faktisk er «tekniske» fordeler knyttet til størrelse eller samdrift, og om disse kan la seg realisere i praksis. Ingebrigtsen og medarbeidere beskriver (fra sitt ikke-nøytrale ståsted) en prosess hvor sammenslåingen ble gjennomført med det de kaller en kunnskapsbasert tilnærming, og antyder vel med det at prosessen har vært viktig for det som kan se ut som et vellykket resultat.

Om en prosess blir vellykket, vil både være avhengig av hvordan den gjennomføres og av hvilke målsettinger de ulike aktørene går inn $\mathrm{i}$ arbeidet med. I den klassiske beskrivelsen av legeprofesjonen betraktes leger som sosialisert inn i en kultur preget av sterk faglig autonomi, medisinsk rasjonalitet, og faglig engasjement (8). Noe enkelt kan vi si at mens legene ofte vil være orientert mot «mikro» og den enkelte pasient, vil ledelse og administrasjon i større grad vektlegge «makro» dvs. befolkning og system (9). Vi står dermed overfor en mulig interessekonflikt, og hvis denne ikke håndteres godt i endringsprosesser, vil resultatet lett kunne bli dårlig. Vi vet fra studier i Norge $(9,10)$ at leger ofte er skeptiske til reformer som oppleves truende mot deres faglige autonomi, men vi vet også at skepsisen er mindre hos leger som har rollen som ledere og administratorer (9). Om dette også betyr at endringer som forankres i ledere med legebakgrunn vil ha lettere for å gi et godt resultat gjenstår å se.

Studien til Ingebrigtsen og medarbeidere gir antydninger til optimisme med hensyn til at det faktisk er mulig å realisere noen av de effektene som enkle økonomiske betraktninger sier oss er der. Etter år med sykehussammenslåinger er det likevel grunn til å antyde tre forhold som bør være avklart før man fortsetter med å slå sammen sykehus. For det første bør det være en selvfølge at det ligger en faglig dokumentert kalkyle over (teoretiske) gevinster til grunn for en beslutning om sammenslåing. For det andre må det også foreligge en beskrivelse av hvilke organisatoriske forutsetninger som må være oppfylt for at disse skal kunne realiseres. For det tredje må prosessen være beskrevet på en slik måte at man underveis kan identifisere hvorfor ting (ikke) går som planlagt. $\mathrm{Og}$, mens vi venter på dette: Kanskje en studietur til Tromsø kunne være på sin plass?

\section{Jon Magnussen}

jon.magnussen@ntnu.no

Jon Magnussen (f. 1959) er professor i helseøkonomi og instituttleder ved Institutt for samfunnsmedisin, Norges teknisk-naturvitenskapelige universitet.

Forfatter har fylt ut ICMJE-skjemaet og oppgir ingen interessekonflikter.

\section{Litteratur}

1. Ingebrigtsen $T$, Lind $M$, Krogh T et al. Sammenslåing av tre sykehus til ett universitetssykehus. Tidsskr Nor Legeforen 2012; 132: 813-7.

2. Egge A. Apokalyptisk prosess i Oslo universitetssykehus. Tidsskr Nor Legeforen 2010; 130: 2110

3. Kristensen T, Bogetoft P. Pedersen KM. Potential gains from hospital mergers in Denmark. Health Care Manage Sci 2010; 13: 334-45.

4. Choi S, Holmberg I, Löwsted J et al. Executive management in radical change the case of the Karolinska University Hospital merger. Scand J Manage 2011; 27: $11-23$

5. Harris J, Ozgen H, Ozcan Y. Do mergers enhance the performance of hospital efficiency? J Oper Res Soc 2000; 51: 801-11.

6. Kjekshus LE, Hagen TP. Ga sammenslåing av sykehus høyere effektivitet? Erfaringer fra Norge. Tidsskrift for Velferdsforskning 2003; 6: 3-16.

7. Ingebrigtsen T. Helseøkonomiske effekter av sykehussammenslåinger. Tidsskr Nor Legeforen 2010: 130: 940-2.

8. Friedson E. The reorganization of the medical profession. Med Care Rev 1985; 42: 11-35.

9. Martinussen PE, Magnussen J. Resisting market-inspired reform in healthcare: the role of professional subcultures in medicine Soc Sci Med 2011. 73. 193-200.

10. Aasland OG, Hagen TP, Martinussen PE. Sykehuslegenes syn på sykehusreformen. Tidsskr Nor Lægeforen 2007; 127: 2218-21. 